\title{
Bedside iPad videooptagelser som læringsredskab i klinisk psykiatri
}

\section{Cecilie Fog-Petersen}

Projektleder, Forskningsenheden

Region Hovedstaden Psykiatri, Psykiatrisk Center Ballerup

\section{Sidse Arnfred}

Forskningsoverlæge

Psykiatrisk Center, Ballerup og Klinisk forskningslektor, KU

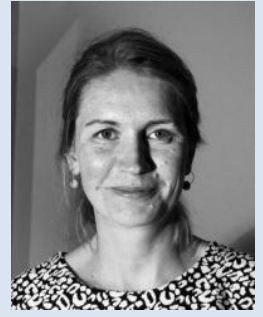

(क)

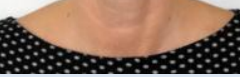




\section{Abstract - English}

This article describes the potentials and challenges of using iPad video recordings as a learning tool for medical students in their psychiatric placement. Seventy-two medical students were instructed in video recording patient interviews and subsequent analysis and reflection with a doctor. Interviews with the students support the idea that iPad video recording has potential as a learning tool, as the iPad opens for detailed analyses of part of the patient interview, for repeated visualization, and for an external perspective, by the student himself, fellow students or doctors. In this manner video recordings support the medical apprenticeship model, but it also adds on an extra analytic dimension. Challenges, which necessarily have to be addressed, seem to mainly stem from the fact that video recording is not part of the authentic working procedures. This undermines an important aspect of the apprenticeship model focusing on the increasing integration of the student in clinical routines.

\section{Abstract - dansk}

I artiklen ser vi på potentialer og udfordringer ved at benytte iPad til videooptagelser til at understøtte lægestuderendes læring under deres klinikophold i psykiatri. 72 studerende er blevet instrueret i at bruge iPads til at filme deres patientsamtaler og gennemse deres patientvideoer med henblik på analyse og refleksion sammen med en læge. Interviews med de studerende peger på, at videooptagelse på iPads har potentiale som læringsredskab, fordi iPaden giver mulighed for at dykke ned i specifikke dele af samtalen, se tingene flere gange og se samtalen mere ude fra, sammen med læge, andre studerende eller alene. På den måde understøtter brugen af iPads mesterlære, men tilføjer også en ekstra analytisk dimension. Der er barrierer, der skal overvindes, som hovedsageligt synes at bunde i, at videooptagelserne ikke er en del af den autentiske praksis og derved underminerer det aspekt af mesterlære, der handler om den studerendes stigende integration i den kliniske hverdag. 


\section{Artiklens afsæt og formål}

Denne artikel tager afsæt i erfaringerne med inddragelse af iPads som videoredskab og støtteredskab til læring og supervision under lægestuderendes klinikophold i psykiatri. Erfaringerne er genereret gennem projektet Intelligent Psychiatric Education Development (IPED), der løb på Psykiatrisk Center Ballerup fra foråret 2013 til sommeren 2014. Artiklens formål er at klarlægge de udfordringer og potentialer, der set i perspektiv af mesterlære, er ved at benytte iPads som videoredskab og støtteredskab til supervision og læring i en psykiatrisk setting

Brugen af videoer som cases eller simulationstræning som læringselementer i medicinsk uddannelse er udbredt (Balslev et al., 2010; Konge et al., 2011), mens brugen af videoer til supervision primært sker i videreuddannelse af læger (J.-H. Larsen, Risør,O., Nystrup, J. \& Charlotte Hedberg, 2010; Muench et al., 2013). På Københavns Universitet (KU) benyttes videoer til supervision af studerende i forbindelse med træning af kommunikation. Brugen af video til supervision af lægestuderende i voksenpsykiatrien er mindre udforsket. Det kan undre, da videoens mulighed for at visualisere det svært beskrivelige og muligheden for at fastholde det øjeblikkelige, er oplagt for at skabe viden i og om psykiatrien. Med udviklingen af redskaber som smartphones og iPads, er det ikke længere nødvendigt med et stort set-up for at kunne filme eller vise videoer, man har optaget. Kamera og skærm er lige ved hånden. Det giver nye muligheder for at benytte videomediet.

\section{Baggrund og motivation}

Flere undersøgelser viser, at psykiatrien i mange år har været lavstatus fag blandt lægestuderende og det har været svært at tiltrække arbejdskraft til psykiatrien(K. Larsen, Bundgaard,B. \& A. Steenberger, 2013). Dette er ikke et særligt dansk fænomen, men genkendes internationalt (Budd et al., 2011; Rajagopal et al., 2004), og medfører blandt andet lægemangel. Alle lægestuderende skal som en del af deres uddannelse beskæftige sig med psykiatri og på uddannelsen til læge ved Syddansk Universitet, Aarhus Universitet og KU, er det obligatorisk, at de lægestuderende skal i klinikophold i psykiatrien (Københavns_Universitet, 2013, 2014;

Syddansk_Universitet, 2013; Aarhus_Universitet, 2011). Et klinikophold er kendetegnet ved, at de studerende i en periode, der er defineret af studieordningen, opholder sig på et eller flere afsnit 
inden for et af de lægelige specialer, for at lære om - og se hverdagen i - specialet.

Ét hold studerende er ofte fordelt på flere hospitaler, men alle i afsnit, der har i samme speciale. Klinikopholdene består oftest af to elementer; den tid de studerende tilbringer på et eller flere afsnit og det, der her omtales som klinisk holdundervisning.

\section{Klinikophold generelt}

Under klinikopholdet får de studerende på afsnittene i et vist omfang lov at observere og afprøve rollen som læge. Denne del af klinikopholdet kan generelt opfattes som en form for mesterlære. Mesterlære-begrebet udspringer af håndværksfagene, hvor lærlinge blev oplært i faget ved at følge svende og mester, udføre arbejdsopgaver og blive korrigeret af de mere erfarne i feltet (Kvale \& Nielsen, 2013; K. Nielsen \& Kvale, 2003). I dag er størstedelen af håndværksfagene bygget op som vekseluddannelse, hvor der veksles mellem undervisning i skoleregi og deltagelse i produktion i praksis (Kvale \& Nielsen, 2013). Denne vekslen ses også i lægeuddannelsen (Egan \& Jaye, 2009; Stalmeijer et al., 2009).

Mesterlære-begrebet blev i 1980'erne redefineret til at vægte den socialiseringsproces, der foregår, når den studerende under sit ophold praksis, bevæger sig dybere fagligt ind i praksisfeltet i integrationen med det tilhørende sociale praksisfælleskab (Lave, 2003). Socialiseringsprocessen i det autentiske arbejdsmiljø tilskrives at virke motiverende på de studerende og at give en forståelse for, hvorfor de skal lære det, studieplanen peger på. Samtidig sker der en forhandling af det faglige indhold, fordi den kliniske praksis er bundet af prioriteter i forhold til produktionen i form af patientbehandlingen (Egan \& Jaye, 2009; Stalmeijer et al., 2009).

Den kliniske holdundervisning, der oftest også er en del af klinikopholdet, foregår på det afsnit eller hospital, de studerende er tilknyttet. Oftest vil en af de studerende være udvalgt til at optage journal med en patient med en specifik lidelse inden holdundervisningen. Journaloptagelse er et af grundelementerne i rollen som læge. Den studerende vil så under holdundervisningen, med patientens tilstedeværelse, gennemgå journalen foran resten af de studerende på afsnittet og en undervisende læge, der kan komme med supplerende spørgsmål til patienten og journalen. 


\section{Målet for klinikophold i psykiatri}

Målet for klinikopholdet i det medicinske speciale psykiatri er, at de studerende skal lære at foretage en psykiatrisk undersøgelse. Den gode psykiatriske undersøgelse forudsætter:

- kendskab til de psykopatologiske fænomener.

- vurdering af aktuel psykisk tilstand.

- kompetent og indlevende kommunikation.

- $\emptyset$ velse i tolkning af patientens udsagn.

For at lære dette, er det naturligt, at den studerende og lægen diskuterer patientens udsagn og de fortolkningsmuligheder, der er, efter at den studerende har været med til en lægesamtale. Tanken er, at den studerende på sigt under opholdet også har samtaler alene med patienten for at øve journaloptagelse. Her er der samme behov for diskussion og analyse efterfølgende. Samtidig kan nogle af patienternes symptomer være mere eller mindre synlig, $\mathrm{fx}$ ved fysisk uro, manglende øjenkontakt eller tics. Det er noget af det, den studerende skal trænes i at observere. I begge situationer kan den studerende komme til kort med at huske udtryk, ordvalg og kontekst, især hvis den studerende samtidigt er uøvet i at få indhentet syge- og livshistorie, som er en del af undersøgelsen og journaloptagelsen.

Helt traditionel mesterlære-tilgang udfordres dog af, at mange af de kompetencer, der skal læres i psykiatrien, ikke er praktiske, men i høj grad omhandler tænkning (Parnas et al., 2013). Psykiatriens kernefelt, som $\mathrm{fx}$ kendskab til de psykopatologiske fænomener og tolkning af patientens udsagn, er abstrakt og vagt set i forhold til mange andre lægelige specialer. Desuden udfordres muligheden for mesterlære yderligere af, at kortere indlæggelser gør det sværere at skabe kontinuitet i mesterlære forløbene, af større produktionskrav samt af speciallægemangel (Varma, 2012).

\section{Projektidé}

For at imødekomme udfordringerne i forhold til mesterlære, har vi på Psykiatrisk Center Ballerup afprøvet iPads som et hjælperedskab til læring i projektet IPED. IPED er udviklet og afprøvet over et år (sommeren 2013 til sommeren 2014) på 6 hold lægestuderende fra KU, der har været i klinikophold i Psykiatrisk Center Ballerup. Hovedformålet med projektet var at afprøve, om brug af bedside videooptagelse og feedback i den kliniske psykiatri-undervisning 
kunne styrke de studerendes kompetence til at gennemføre en psykiatrisk undersøgelse og stille en diagnose. Videooptagelser af patienter har været brugt siden 1930'erne som undervisningsmateriale og demonstrationer. Den ny ide var at lave autentiske videooptagelser "på stedet" under den studerendes almindelige patientsamtaler i det psykiatriske afsnit. I gængs medicinsk litteratur kaldes det bedside, når læge/studerende samtaler ved patientsengen på hospitalet, men psykiatriske patienter ligger sjældent i sengen, når de taler med læge/studerende. Derfor kalder vi i denne artikel de videooptagelser, de studerende laver, for bedside videooptagelser.

Ved at videooptage samtaler med patienter kan den studerende bagefter gennemse samtalen og samle op på det, den studerende ikke opfatter i første omgang samt gennemse dele af videoen med lægen som grundlag for afklaring og diskussion. Tidligere erfaringer peger på, at supervision eller refleksion over video af egen praksis skaber ny læring (J.-H. Larsen, Risør,O., Nystrup, J. \& Charlotte Hedberg, 2010; Ørngreen \& Ratleff, 2011). Med iPads som videoredskab er der let mulighed for at filme og, på en tilstrækkelig stor skærm, at se videoen og få feedback uafhængigt af sted og tid. Man kan bevæge sig frem og tilbage i videoen på iPaden, samt se dele af samtalen flere gange, hvilket naturligvis ikke er muligt under selve samtalen med patienten.

Derfor var det forventningen, at brugen af iPads ville kunne øge læringsudbyttet af den enkelte patientsamtale og skabe en mere fleksibel ramme for mesterlæresituationerne og derved imødegå de tidligere nævnte udfordringer. For at give rum til at udnytte den fleksible ramme, var det lagt op til læger og studerende selv at afgøre, hvornår det var relevant at benytte iPaden og give feedback.

IPads blev valgt ud fra brugervenlighed og forventningen om, at iPads som brand ville skabe velvilje blandt de studerende.

Inden igangsættelsen af projektet blev eventuelle udfordringer diskuteret. Særligt blev det forventet at lægerne ville være modstræbende pga. tidspres og teknologi-angst, men vi forventede også, at der kunne være modstand blandt plejepersonalet på afsnittene. Der var dialog om, hvorvidt patienterne ville filmes, men med hverdagens store brug af socialmedier som instagram, Facebook og andre sociale netværk (Nielsen, 2013), vurderede vi, at en stor del af patienterne ville indvillige $i$ at blive filmet. Vi forventede, at de http://www.lom.dk 
studerende ville være engagerede og nysgerrige på at afprøve et nyt læringsredskab.

\section{Strukturen på klinikopholdet på Psykiatrisk Center Ballerup}

De studerendes klinikophold var overordnet struktureret over fem uger á fire dage. De studerendes ophold var planlagt, så de om formiddagen var fordelt på forskellige afsnit og de fleste eftermiddage samledes til holdundervisning. Til holdundervisningen var der, i det omfang det var muligt, en patient med.

En typisk uge:

\begin{tabular}{|l|l|l|l|l|l|}
\hline Dag & Mandag & Tirsdag & Onsdag & Torsdag & Fredag \\
\hline $\begin{array}{l}\text { Formid } \\
\text { dag }\end{array}$ & På afsnit & På afsnit & På afsnit & På afsnit & $\begin{array}{l}\text { Tema- } \\
\text { dag på } \\
\text { universi } \\
\text { tetet }\end{array}$ \\
\hline $\begin{array}{l}\text { Eftermi } \\
\text { ddag }\end{array}$ & $\begin{array}{l}\text { Hold- } \\
\text { undervis } \\
\text { ning }\end{array}$ & $\begin{array}{l}\text { Hold- } \\
\text { undervis } \\
\text { ning }\end{array}$ & $\begin{array}{l}\text { Hold- } \\
\text { undervis } \\
\text { ning }\end{array}$ & $\begin{array}{l}\text { Hold- } \\
\text { Undervis } \\
\text { ning }\end{array}$ &
\end{tabular}

Udover at bruge videoerne fra afsnittene til eget brug eller til feedback fra læger, fik de studerende også til opgave lave en video med en patient, der skulle bruges til en særlig holdundervisningsgang. Denne undervisningsgang blev bygget op om de studerendes videoer, uden tilstedeværelse af patient til selve undervisningen.

\section{Udlevering af og instruktion til iPads}

På første dag i deres klinikophold fik hver studerende udleveret en iPad. iPads'ne var iklædt et beskyttelsescover, der gav mulighed for, at iPaden kunne stå oprejst samtidig med, at den var sat til at filme.

Samtidig med udleveringen af iPads, blev de studerende præsenteret for projektet og fik en times instruktion i basal brug af iPadens indbyggede kamera, appen iMovie (mulighed for at spole i videoen), slette videoen samt guidelines til at komme i gang med at filme patienterne. De fik udleveret et skriftligt instruktionshæfte, hvori der også var et skema til at registrerer de patienter, de fik filmet. Introduktionen og materialet var udarbejdet med erfaringerne fra et 
pilothold, hvor iPads blev afprøvet. Materialet blev redigeret løbende ud fra de studerendes feedback gennem projektforløbet. Når de studerende modtog iPaden, var der følgende materiale på den:

\begin{tabular}{|c|c|c|}
\hline Apps: & Introduktionsvideoer: & Andet materiale: \\
\hline $\begin{array}{l}\text { - } \text { iMovie } \\
\text { - } \text { pdfpen } \\
\text { - } \text { Fileapp } \\
\text { - Officereader }\end{array}$ & $\begin{array}{l}\text { - Hvordan man sætter iPaden til at } \\
\text { filme. } \\
\text { - Introduktion til patient ved læge. } \\
\text { - Hvordan får man patienten til at } \\
\text { underskrive. } \\
\text { - Hvordan ser man video igennem } \\
\text { med læge. }\end{array}$ & $\begin{array}{l}\text { - } \text { Materiale fra } \\
\text { introduktionsdag. } \\
\text { - } \text { Instruktion til IPED og } \\
\text { brug af iPads til at filme. } \\
\text { - } \text { Introduktion til } \\
\text { samtaleteknik. } \\
\text { - Slides fra undervisning. }\end{array}$ \\
\hline
\end{tabular}

IPad og fysisk materiale blev udleveret i en mulepose, så de studerende let kunne transportere det rundt. Her efter var det op til de studerende at få brugt iPaden, når de var på afsnittene.

Introduktion til læger, plejepersonale og patienter For at klæde lægerne på til at understøtte de studerendes brug af iPads, blev lægerne introduceret til det at give feedback på en iPad video på morgenmøder og til fællesundervisning. Vi vurderede at denne form for feedback krævede en ekstra indsats fra lægerne (J.-H. Larsen, Risør,O., Nystrup, J. \& Charlotte Hedberg, 2010) og en del af lægerne deltog i en $2 \frac{1}{2} 2$ dages workshop om at give feedback ud fra videooptagelser. Hver afsnit blev informeret ved ophængte plakater, uddelte brochurer og e-mails.

Patienterne blev informeret om projektet via brochurer og mundtligt ved introduktion gennem den studerende, der aktuelt ønskede at filme en patient.

\section{Personfølsomme data og adgang til internet}

I forbindelse med at optage videoer af patienter, skal patienterne altid informeres og der skal indhentes samtykke fra patienten. Vi valgte at lave to typer af samtykkeerklæringer, en hvor patienten gav sit samtykke til, at den studerende kunne opbevare og bruge videoen med en læge eller medstuderende i 14 dage og en udvidet samtykkeerklæring, hvor patienten indvilligede i, at videoen kunne bruges til undervisning på længere sigt. 
Den store udfordring ved at bruge iPads til at filme patienter er, at der kun er fă trin fra at have lavet en video med iPaden til, at videoen er lagt på nettet via fx YouTube. Videoer, der viser ansigt eller stemmer af patinter, anses ifølge datatilsynet at være personhenførbare data, hvorfor det ikke er lovligt, at videoerne af patientsamtalerne kan ende på internettet. For at undgå dette, havde de studerende kun adgang til trådløst internet med deres iPads i ét lokale på Psykiatrisk Center Ballerup (det lokale holdundervisningen blev foretaget i). De studerende blev desuden pålagt at behandle iPaden med samme forholdsregler som en patientjournal, dvs. ikke at tage den med hjem, hvis der lå en video af en patient på deres iPad, men at opbevare den, i de dertil opstillede aflåste, kodede, værdiskabe på matriklen.

Inden projektet blev igangsat, blev datatilsynet kontaktet for at sikre, at lovgivningen for håndtering af personfølsomme data blev overholdt. Den begrænsede adgang til nettet, oprettelse af personlig kode til iPaden og opbevaring af iPaden i værdiskab bag låste døre på matriklen, når den ikke var i brug, blev af datatilsynet vurderet at overholde lovgivningen.

Hvor begrænsningen for netadgang på den ene side sikrede, at persondataloven blev overholdt, undergravede den på den anden side en del af iPadens primære funktioner, fx faglig søgning på nettet. Desuden understøttes iPads ikke af Region Hovedstadens IT, hvorfor de studerende ikke havde adgang til intranettet via deres iPads.

Ved klinkopholdets afslutning afleverede de studerende iPaden tilbage, alt materiale på dem blev slettet, og iPaden blev geninstalleret som ny, inden en ny studerende overtog den.

\section{ÆEndringer for praksis i projektforløbet}

Midt i projektforløbet blev det besluttet, at organiseringen af lægebemandingen på de forskellige afsnit på Psykiatrisk Center Ballerup skulle ændres. Dette fik betydning for fordelingen af de studerende på de forskellige afsnit, men har særligt haft betydning for lægerne, der har brugt lidt tid på at falde på plads i den nye struktur.

En anden udfordring midtvejs i projektet var, at appen iMovie blev opdateret og derved ændredes funktionerne, som de studerende skulle bruge. Ændringen var så radikal, at appen ikke længere var 
ligeså brugervenlig som tidligere. Det betød også, at der måtte foretages større ændringer af instruktionsmaterialet.

\section{Indsamling og bearbejdning af data}

Fem af de seks hold lægestuderende blev ved gruppeinterviews interviewet om, hvordan iPaden virkede som læringsredskab. Den samme spørgeguide er gået igen i alle interviews, dog med nogle modifikationer.

Interviewene blev optaget, transskriberet og herefter anonymiseret. Analysen af interviewene foregik som meningskondensering, dvs. ved kort at sammenfatte de enkelte udsagn med udgangspunkt $\mathrm{i}$ spørgeguiden. Efter gentagende gennemlæsning af de transskriberede blev to gennemgående temaer definereret: "potentialer" og "udfordringer" (Kvale \& Brinkmann, 2009).

\section{Analyse af de studerendes oplevelser}

Som nævnt vil der i analysen være fokus på de potentialer, de studerende så ved brugen af iPad og på de udfordringer, de oplevede i forhold til at bruge iPads - set i lyset af mesterlære.

I mesterlære er der særligt fokus på to processer: 1. vejledning og feedback fra den erfarne til den mindre erfarne, som det ses når den studerende går med og får bedside undervisning af lægen og selv prøver journaloptagelse under observation etc. 2. deltagelse i en autentisk praksis i en bevægelse fra legitim perifer deltagelse til fuldt integreret aktør i arbejdsfællesskabet (K. Nielsen \& Kvale, 2003), som det ses, når den studerende indgår i dagliglivet i afdelingen, går til konferencer med læger og tværfagligt personale og hjælper til, hvor de kan. I forhold til disse to delaspekter af mesterlære, bliver udgangsspørgsmålene:

- Hvilke læringspotentialer giver de studerendes brug af bedside iPad videooptagelser?

- Hvilke udfordringer er der for de studerendes ved at bruge bedside iPad videooptagelser?

Det fremgik også af vores interviews, at der var både fordele og ulemper ved at have en iPad med sig rundt i afdelingerne, som ikke relaterede til iPaden som video-redskab. Det beskriver vi kort til sidst i analysen. 


\section{Læringspotentiale ved bedside iPad videooptagelser}

Hvor meget iPaden har været brugt, svinger fra studerende til studerende. En af de studerende, som have en læge som mentor under klinikopholdet, fortæller, hvordan iPaden var gavnlig, da den studerende sammen med lægen kiggede på en video af en patientsamtale:

\footnotetext{
"... men jeg havde lavet en video, som hun ikke havde været med til, og den har jeg siddet og scrollet i med hende, og så har hun læst min objektivt psykisk[vurdering af aktuel psykisk tilstand], og ja, som flere har sagt, det var faktisk godt"
}

(Studerende 2013)

Med udgangspunkt i videoen kunne lægen, ud fra det den studerende havde set og spurgt til under samtalen, bedømme sammenhængen mellem den studerendes fortolkning af patienten og den studerendes vurdering af patientens aktuelle psykiske tilstand. Der sker på den måde en objektivisering af samtalen, så den kan behandles som et konkret produkt (jf. mesterlære i håndværksfagene), som lægen kan give feedback på. Hvor den studerende uden brugen af iPad mundtligt skulle forklare om patienten, med de muligheder, der ligger for fortolkninger og undladelser, giver videoen mulighed for, at patientens fremtræden, og den studerendes spørgsmål og fortolkning, kan vende og drejes og detailstuderes. Bedside mesterlære understøttes derved, fordi den studerende med iPaden kan vise en video af samtalen.

En anden studerende forklarede, at det, at se videoen med en læge bagefter samtalen, åbnede op for alt det, man ikke selv opdagede under samtalen med patienten. To studerende havde sammen http://www.lom.dk

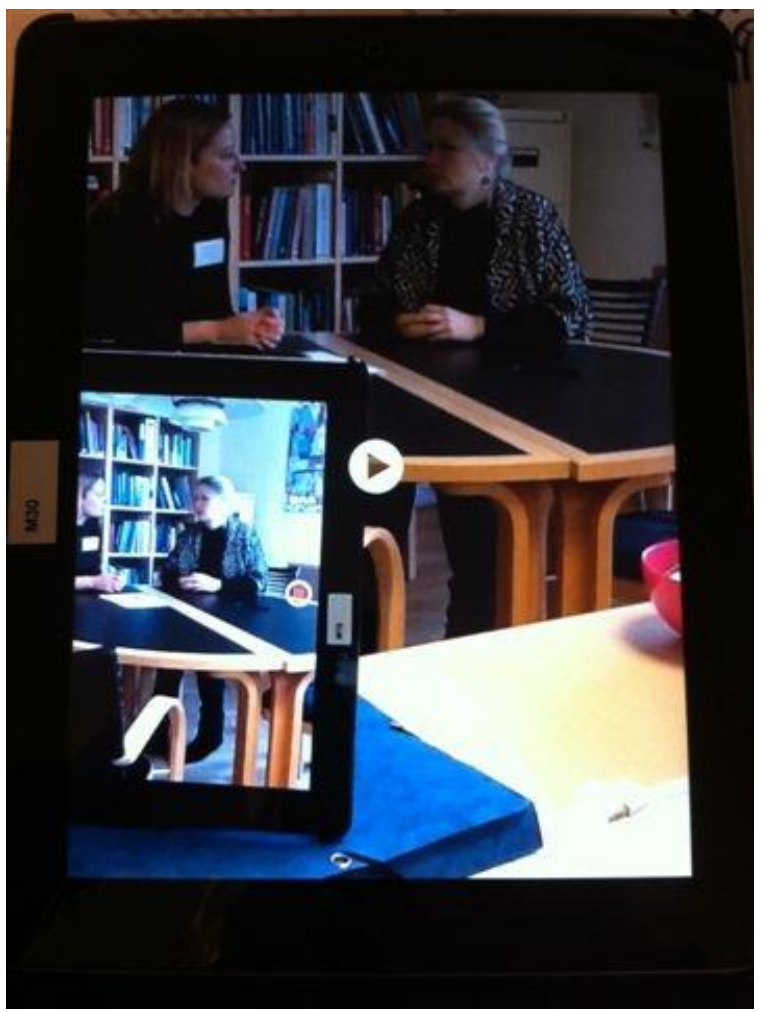


optaget to samtaler, hvor de hver især førte ordet, mens den anden studerende kunne byde ind:

\footnotetext{
"Og der fik vi en læge til at kigge på begge vores videoer. Og selv om at ... altså, når X havde fået optaget så havde jeg siddet inde i rummet samtidigt, og der var det ret interessant at se, selv om vi havde siddet to i det samme rum og under den samme samtale, og også selv havde budt ind med vores egne ting, så var der faktisk ret mange ting som vi ikke havde lagt mærke til, også selv om vi havde snakket ret uddybende om det bagefter."
}

(Studerende 2014)

Igen beskrives en situation, hvor lægen kan tage udgangspunkt i videoen af samtalen som et konkret produkt, for sin supervision. Samtidig forklarer citatet, hvordan visualiseringen af samtalen gav de studerende mulighed for at se det, der under samtalen var usynligt.

Flere andre studerende beskriver samme type situationer som lærerige oplevelser, der er tegnet ved, at lægen og den/de studerende har set videoen sammen og haft en dialog omkring den. Dette var ifølge de studerende den ideelle situation, hvis der skulle opnås læring vha. iPad videoer i hverdagen.

Selvom de studerende fandt det ideelt at se videoerne igennem med en læge, havde enkelte studerende også haft stort udbytte af blot se videoen selv:

\footnotetext{
"Men jeg synes også godt man kan få noget ud af at kigge på sig selv, altså bare sådan se den video, selv om det er meget bedre at få en læge til at sige, hvad man gør rigtigt og forkert. Så synes jeg også godt man kan få lidt ud af bare sådan at se, hvordan man selv spørger ind, og hvordan det virker på patienten og sådan set lidt ude fra bagefter."
}

(Studerende 2014)

Denne studerende er en af de få studerende, der benyttede iPaden til at se på sin samtaleteknik. Samtidig er denne studerende en af de få, der giver udtryk for, at man kan få udbytte af at se sin video alene. Det har værdi i sig selv, at man med videoen kan se sig selv ude fra bagefter. Her giver iPaden altså mulighed for detaljeret observation og refleksion over eget produkt (samtalen) uden mester. 
En anden studerende forklarede, at iPaden gav mulighed for at se patients adfærd i samtalen flere gange, hvilket jo ikke ellers er muligt. Den studerende oplevede at få bedre mulighed for at vurdere patientens aktuelle psykiske tilstand, en opgave de studerende generelt fandt udfordrende, fordi vurderingen er bygget op om abstrakte begreber. Med iPaden kunne den studerende spole frem og tilbage og dykke ned i enkelte bidder af samtalen.

Mange af de studerende gav udtryk for, at de første samtaler med patienterne var en udfordring både fagligt og mentalt. Fagligt, fordi de kun havde ganske lidt kendskab til feltet og mentalt, fordi det at stå frem med sin manglende faglighed føltes grænseoverskridende.

\footnotetext{
"Jeg synes bare, at man føler et pres på en eller anden måde ... ja, lægen kan afbryde og så ... det ved jeg ikke, jeg synes bare, at det var mere behageligt, at det bare var en iPad, der stod der."
}

(Studerende 2013)

Med iPaden kunne den studerende undgå presset ved at blive observeret af en læge og kunne bagefter selv vælge dele ud, som lægen skulle se.

Samlet set synes iPad videoer at understøtte bedside mesterlære, fordi videoen øger både den studerende og lægens mulighed for at gentage, detailstudere og pointere symptomer, fund og samtaleteknik. Herved opnår den studerende indsigt både ud fra sine egne erfaringer og lægens, altså en forstærkning af en typisk mesterlæresituation.

\section{Udfordringer ved brug af bedside iPad videooptagelser}

Det var i projektets første fase en udfordring at informere lægerne og plejepersonalet på afsnittene om brugen af iPads og at implementere brugen af iPads som et redskab i de studerendes dagligdag på afsnittene. Brugen af videooptagelser og feedback på videooptagelser er ikke en almindelig procedure i afsnittene og derved ikke en autentisk del af hverdagen. Det kan forklare, hvorfor de studerende har oplevet, at plejepersonalet i nogle tilfælde var imod brugen af iPad videooptagelse.

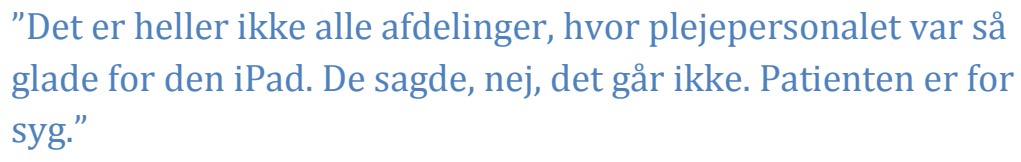
glade for den iPad. De sagde, nej, det går ikke. Patienten er for syg." 
Denne studerende oplevede, at lægen sagde god for, at patienten kunne filmes, mens plejepersonalet ikke havde samme holdning. Andre studerende har oplevet lignende situationer, og det har endda ført til diskussioner mellem læge og plejepersonale. Det gav bestemt ikke de studerende mere mod på at spørge, om de måtte filme patienterne. Derudover var Psykiatrisk Center Ballerup som nævnt præget af lægemangel, hvilket betød et stort arbejdspres på de ansatte læger. Arbejdspresset og lægemanglen fik også konsekvens for de studerendes oplevelse af mulighederne for at få feedback på deres videoer:

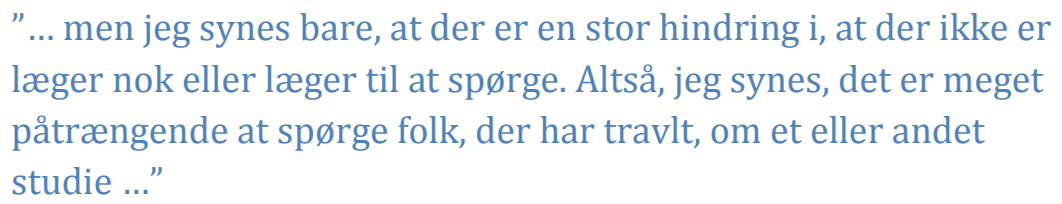

Supervision af en video bliver her, af den studerende, forstået som en ekstra opgave i den i forvejen travle kliniske hverdag, og det indgår ikke naturligt i det kliniske arbejde. Arbejdet med videoen kommer således heller ikke til at understøtte bevægelsen fra en legitim perifer position til at være en integreret aktør i arbejdsfællesskabet (K. Nielsen \& Kvale, 2003). At bruge tid på videoen hjælper altså ikke den studerende ud af den perifere position, men understreger i stedet den positionen, fordi videoen ikke opleves som et autentisk klinisk redskab.

Brugen af iPads var i projektet bygget op omkring de studerendes møde med patienter og patienternes velvilje til at blive filmet. Fordi afsnittene var presset af lægemangel, oplevede de studerende, at det var svært for dem at komme til patienterne, både sammen med en læge og alene. Af interviewne fremgår det desuden, at nogle af patienter ikke ønskede at tale med de studerende, og flere studerende har ydereligere oplevet, at en stor del af patienterne ikke $\emptyset n s k e d e$ at blive filmet. Hvorfor de ikke ønskede at blive filmet, fremgår ikke af interviewene. En del af de studerende har også selv været tilbageholdende med at spørge patienterne, om de ville filmes:

"Jo, men jeg synes bare ... jeg prioriterer i hvert fald bare at få noget kontakt med patienterne, og så må jeg lægge den iPad et http://www.lom.dk 
andet sted, og så kan jeg snakke med patienten i stedet for at ødelægge kontakten ved at presse på med at tage video."

(Studerende 2013)

En del af de studerende har altså været påholdende med at spørge patienterne, om det var ok at filme samtalen, fordi de forestillede sig, at der var risiko for at få en dårligere samtale, eller som andre studerende påpeger: slet ikke at få lov at tale med patienten. Her fremstår bedside videooptagelsesproceduren således som en barriere for at indgå i mesterlære.

Mange af de studerende oplevede det som grænseoverskridende at skulle spørge patienterne om de måtte filme, både fordi de i forvejen følte, at de var til gene for patienten, og fordi de ikke selv ville bryde sig om at blive filmet, hvis de selv var indlagt. Dertil kommer, at de studerende har modstand mod at filme, fordi de risikerer at blive konfronteret med sig selv på video:

\footnotetext{
" ...det er mere det der med både at blive konfronteret med sig selv, altså man synes, det er akavet nok i forvejen, men også at skulle vise det til nogen."
}

(Studerende 2013)

Den objektivisering, som patienten udsættes for i det kliniske arbejde, bliver mere tydelig når patientens fremtræden fastholdes på video, og det synes at vække en modstand i de studerende. De synes at opleve det psykiatriske genstandsfelt som særligt intimt.

Den bedømmelse, som indgår i mesterlæren opleves også stærkere, når den studerendes indsats er fastholdt på video, det opleves ubehageligt af nogle studerende.

Af interviewene fremgår det, at nogle studerende oplevede iPaden som unødvendig, hvis de direkte efter en patientsamtale havde mulighed for at drøfte samtalen med en læge:

\footnotetext{
"Ja, for jeg kunne sagtens gå ud og forklare situationen: vi snakkede om det og det, og så gik jeg lidt i stå. Hvad kunne jeg have gjort? Det behøves ikke at se videobåndet for at få svar på det."
}

(Studerende 2013) 
Denne studerende oplevede ikke et behov for iPadens visualiseringsmuligheder i forhold til at forklare lægen om en samtale. En anden studerende stillede under samme interview spørgsmålstegn ved om den tidsmæssige ressource, der ligger i at filme, se videoen igennem og udvælge dele, er rimelig, i forhold til det faglige udbytte. Den studerende oplevede, at den tid der skulle bruges på at få udbytte af videoen, ville give et større udbytte ved fx at blive brugt på at læse. De to studerende så altså ikke videooptagelse som en hjælp. Andre studerende påpegede, at de ikke oplevede at få noget ud af iPaden, fordi de ikke havde mulighed for at få feedback på deres videoer.

Samlet set er der enkelte studerende der ikke synes, at fordelene ved at supplere bedside mesterlære med videooptagelser kan betale sig i forhold til de tidsmæssige ressourcer, det koster. Til gengæld er det overordnede indtryk, at det, at de studerende introducerer et nyt redskab i den kliniske hverdag, udgør en forstyrrelse i deres integrationsproces. Videooptagelserne udgør et brud på den autentiske praksis, fordi det ikke er en metode, der indgår i patientbehandlingen eller benyttes af det faste personale i afdelingerne.

Andre aspekter ved at have en iPad med i den kliniske hverdag De studerende beskriver, at iPaden havde flere gode praktiske funktioner.

Nogle studerende benyttede iPaden som skriveredskab ikke mindst pga. den dens mobilitet.

\footnotetext{
"Jeg har brugt min til at skrive på. Det har været rigtig dejligt at have sådan en bærbar computer med rundt og skrive journal på den. Så kan man lige fange lægen uden at man skal finde en printer og alt muligt, når man har skrevet et notat. Det er den godt til, men den er måske lidt som en skriveblok."
}

(Studerende 2013)

I løbet af projektet blev der fyldt mere og mere undervisningsmateriale på iPaden, som gav læsestof i vente- og forberedelsesperioder. Med materialet fik de studerende, som denne studerende nævner, bedre mulighed for selv at klæde sig på før en patientsamtale. 
"Jeg har brugt nogle gange at sidde og kigge lidt på nogle af de der dokumenter der lå, altså. Nogle af de der spørgsmål f.eks. der lå inde under, det der PSE, present state examination, hvor det var sådan meget fint sådan ligesom, nå ja, depression, så kan jeg spørge om alle de her ting. Det synes jeg faktisk var ... det kiggede jeg lidt på inden jeg skulle ind og tale med en patient."

(Studerende 2014)

Derudover kunne videooptagelserne bruges til den kliniske holdundervisning, fordi patienterne ikke altid var villige til at deltage. At sidde og overvære en studerende læse højt af en patientjournal uden patientens tilstedeværelse, fandt de fleste studerende uinteressant. Der var det hjælpsomt med en video. Samtidig beskrev de studerende, at patienterne kunne fremtræde anderledes, når de var med til holdundervisning end når den studerende optog journal med patienten.

\footnotetext{
"Ofte ændrer det sig, synes jeg. Det virker som om at når man har snakket med en patient om formiddagen, så har de nogle bestemte symptomer og sådan noget, og når de så kommer op til klinikjournal og sidder og snakker med os, så er det ikke helt på samme måde som den, som har skrevet journalen har beskrevet. Så kunne det være fint at se, hvordan vedkommende ændrer sig."
}

(Studerende 2013)

Endelig fremsatte de studerende en række forslag til hvordan, iPaden også kunne udnyttes i klinikken. Se tabellen med de studerendendes forslag:

\begin{tabular}{|c|c|c|}
\hline Materiale på iPads & $\begin{array}{l}\text { Andre der kunne } \\
\text { få glæde af } \\
\text { iPads/videoer }\end{array}$ & $\begin{array}{l}\text { Hvad videoer ellers } \\
\text { kunne bruges til }\end{array}$ \\
\hline $\begin{array}{l}\text { - Journalkonceptet } \\
\text { - Diagnosekoder } \\
\text { - Litteratur } \\
\text { - Word } \\
\text { - Opus } \\
\text { - Medicinregistrering } \\
\text { - Lægehåndbogen }\end{array}$ & $\begin{array}{l}\text { - Forvagterne ville } \\
\text { få meget ud af at } \\
\text { bruge dem } \\
\text { - Somatikken } \\
\text { - Patienterne } \\
\text { kunne se sig selv } \\
\text { på video som en } \\
\text { del af deres }\end{array}$ & $\begin{array}{l}\text { - Gemme klip til } \\
\text { senere } \\
\text { brug(undervisning) } \\
\text { - Lægge video i } \\
\text { journaler så man kan } \\
\text { se forbedringer } \\
\text { - Læger kunne filme } \\
\text { eksempler }\end{array}$ \\
\hline
\end{tabular}




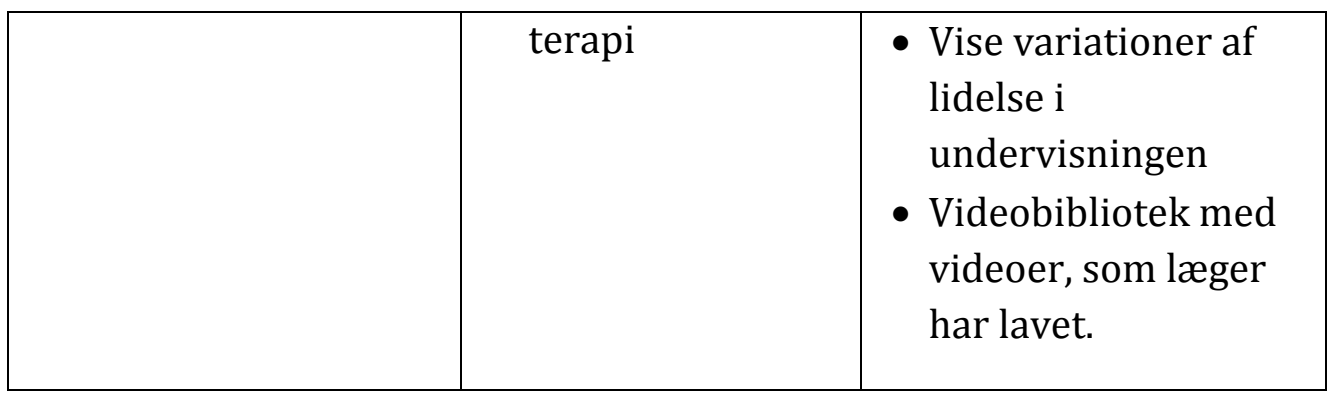

De studerende beskrev også en række praktiske udfordringer. Nogle fandt det generende, at de ikke måtte tage iPaden med hjem, når der var video af patienter på. Nogle studerende var generet af, at de ikke bare kunne møde ind med iPaden i tasken om morgnen, men først skulle forbi værdiskabet for at hente den. Trods iPadens relativt lille størelse oplevede flere studerende også, at iPaden var besværlig at gå rundt med på afsnittene.

\footnotetext{
"...og så har man ikke rigtig lyst til at have den med, fordi ellers så bærer man bare rundt på det, den vejer, og den fylder meget, og man får den ikke brugt til noget, fordi hvis man godt kunne bruge den samtidig, som man bruger sin telefon eller en computer til at slå alt muligt op og skrive noter på, så kunne det være fint, men man gider ikke rigtig have den med..."
}

(Studerende 2013)

\section{Diskussion}

Samlet set fremgår det, at de fleste studerende, der har fået brugt deres iPads, har oplevet at lære noget ved det, og de ser også iPaden som et praktisk instrument. I analysen har vi også vist, at bedside iPad videooptagelser i den kliniske hverdag i særlig grad understøtter og tilføjer noget til mesterlære, men også at videooptagelserne opleves som en forstyrrelse af de studerendes integration i afdelingens autentiske arbejde. Samtidig peger analysen på, at projektet har været præget af en række udfordringer af teknisk og praktisk karakter, såsom de studerendes manglende incitament til at bruge iPads og læger og plejepersonales beskedne opbakning.

Det var et gennemgående tema, at det var en stor udfordring var at få lavet filmene, en udfordring der både affødtes af de studerende, af patienterne og af personalet. Det kan diskuteres hvorvidt, denne modstand handler om de studerendes usikkerhed, stigma i psykiatrien eller noget tredje. De studerende bemærker, at det har http://www.lom.dk 
betydning, hvordan patienterne bliver spurgt, om de vil filmes og analysen viser, at nogle studerende har haft svært ved at få sig selv til at spørge patienterne. Modstanden mod at filme og blive filmet, går imod projektets antagelse om, at med tidens brug af sociale medier og de mange billeder, der lægges på nettet den vej, ville der ikke være modstand mod at filme og blive filmet (K. Ø. Nielsen, 2013 ). De studerendes egen modstand mod at filme, kan handle om flere ting. En type modstand går på at iPaden er besværlig at have med. Af artiklen "A review of video review: New processes for the $21^{\text {st }}$ Century" fremgår det, hvordan uddannelseslæger i en amerikansk lægepraksis havde modstand mod udstyret, fordi det var besværligt, og at patienterne klagede over, at der altid stod et kamera fremme. Med succes gik man over til at filme med iPods, der kunne sættes op i en holder på væggen (Muench et al., 2013). Det kunne pege på, at iPaden som redskab er et forkert valg. Dog ville brugen af iPods mindske den fleksibilitet, der er ved at kunne se videoen hvor som helst, fordi skærmen på en iPod er meget lille. Desuden viser vores analyse, at iPaden som redskab ikke er det eneste, der holder de studerende tilbage. Det, at skulle konfronteres med sig selv på video udgør også en barriere. At man føler sig sårbar, når man skal vise sig selv på video til andre, bekræftes af erfaringerne fra både almen praksis og psykoterapi supervision (J.-H. Larsen, Risør,O., Nystrup, J. \& Charlotte Hedberg, 2010; Muench et al., 2013; Ørngreen \& Ratleff, 2011). At blive filmet og fastholdt på film er ikke bare sårbart for den studerende, men også for patienten (Schen, 2012), og det må overvejes, om både patienternes og de studerendes modstand mod at blive filmet, hænger sammen med den stigmatisering, som psykiatrien er præget af (Iezzoni et al., 2006).

Nogle af de studerende sætter spørgsmålstegn ved, om de tidsmæssige ressourcer, der går til video supervision svarer til læringsudbyttet. Det er uklart, om det er et udtryk for manglende forståelse af iPadens muligheder, konservativ tænkning eller deres reelle oplevelse. Men det får os til at overveje, om en grundigere introduktion eller mere opfølgning kunne have øget de studerendes forståelse for læringsmulighederne med iPads og derved deres incitament for at bruge den. Gennemgang af andre projekter, hvor implementeringen af nye læringsredskaber er mere vellykket, viser, at der har været opbygget en stærkere struktur med tæt opfølgning og incitament, som fx faste afleveringer, gruppearbejde eller fastlagt feedback. Dog er disse projekter udført i skole-regi og ikke ude i klinisk praksis i en organisation hvis hovedformål ikke er http://www.lom.dk 
uddannelse. (M. R. Dahl, Svanholm, A.S., 2013; M. R. S. Dahl, A.S., 2013; Ørngreen \& Ratleff, 2011). Selvom alle de studerende havde forstået og været motiveret for at lave videoer, er det fortsat et relevant spørgsmål, om de tidsmæssige ressourcer, der går på at se videoen igennem igen efter samtalen og at finde klip til lægen, svarer til læringsudbyttet. Ud fra vores egen analyse synes mesterlære med bedside videooptagelserne at byde på mere end vanlig mesterlære. Man har mulighed for gentagelse, for at fange det man har overset og for at se situationen ude fra, med nye øjne. Disse muligheder fremhæves også i Lars-Helge Larsens beskrivelse af gruppesupervision af videooptagede samtaler i almen praksis (J.-H. Larsen, Risør,O., Nystrup, J. \& Charlotte Hedberg, 2010).

Der er ingen tvivl om, at de studerende, der har brugt iPad-videoer til at få fedback ud fra, har fået noget ud af det, men iPadens potentiale i forhold til supervision på egen teknik og beslutningsproces samt egen refleksion, udnyttes dog kun i beskeden grad af de studerende. Derimod ser de studerende stort potentiale i at bruge videofilm til holdundervisningen og bruge iPaden som praktisk redskab. Spørgsmålet bliver derfor om potentialet for refleksion og detailanalyse ligger på så højt et fagligt niveau, at det er højere end de studerendes læringsbehov? Disse de ekstra niveauer, som visualiseringen tilføjer til mesterlære, kunne være et oplagt felt for videre forskning. Andre udestående spørgsmål handler i sær om at blive klogere på modstanden mod at filme: hvilke faktorer gør sig gældende hos de studerende og hvilke hos patienterne? Og hvordan kan de imødegås? I fremtidige studier kunne det være relevant at medtænke observationer, ja endog videooptagelser, for at afdække barriererne bedst muligt (Ørngreen \& Ratleff, 2011).

\section{Konklusion}

Vi har beskrevet vores erfaringer med at benytte iPad videoer som læringsredskab i et mesterlære baseret forløb for lægestuderende på psykiatrisk afdeling. Bedside iPad videooptagelse har potentiale som læringsredskab, fordi iPaden giver mulighed for at dykke ned i specifikke dele af samtalen, se tingene flere gange og se samtalen ude fra, sammen med andre eller alene. På den måde understøtter brugen af iPads mesterlære, men tilføjer også en ekstra analytisk dimension, der bør være fokus for fremadrettet udforskning. Der er barrierer, der skal overvindes, hvoraf nogle synes at være af mere psykologisk karakter, mens andre bunder i, at videooptagelserne ikke er en del af den autentiske praksis og derved underminerer http://www.lom.dk 
mesterlæren. Daglig klinisk brug af videooptagelser til dokumentation og oplæring af læger og sygeplejersker kunne ændre det sidstnævnte aspekt, og det ville være relevant at undersøge om de psykologiske barrierer i så fald også aftog.

\section{Referencer}

Balslev, T., de Grave, W. S., Muijtjens, A. M. M., \& Scherpbier, A. J. J. A. (2010). Enhancing Diagnostic Accuracy Among Nonexperts Through Use of Video Cases. Pediatrics, 125(3), E570-E576. doi: DOI 10.1542/peds.2009-0438

Budd, S., Kelley, R., Day, R., Variend, H., \& Dogra, N. (2011). Student attitudes to psychiatry and their clinical placements. Med Teach, 33(11), e586-592. doi: 10.3109/0142159X.2011.610836

Dahl, M. R., Svanholm, A.S. (2013). Implementering af iPads i undervisningen på Skolen for Klinikassistenter, Tandplejere og Kliniske Tandteknikere (SKT), Aarhus Universitet. (10-2013). http://ojs.statsbiblioteket.dk/index.php/lom/article/view/7290

Dahl, M. R. S., A.S. (2013). Implementering af iPads i undervisningen på Skolen for Klinikassistenter, Tandplejere og Kliniske Tandteknikere (SKT), Aarhus Universitet. (10-2013). http://ojs.statsbiblioteket.dk/index.php/lom/article/view/7290

Egan, T., \& Jaye, C. (2009). Communities of clinical practice: the social organization of clinical learning. Health, 13(1), 107-125. doi: Doi $10.1177 / 1363459308097363$

Iezzoni, L. I., Ramanan, R. A., \& Lee, S. (2006). Teaching medical students about communicating with patients with major mental illness. Journal of General Internal Medicine, 21(10), 1112-1115. doi: DOI 10.1111/j.15251497.2006.0521.x

Konge, L., Ali, A., Sorensen, M., \& Bitsch, M. (2011). [Gender differences among medical students in the approach to simulation]. Ugeskr Laeger, 173(49), 3170-3173.

Kvale, S., \& Brinkmann, S. (2009). Interview : introduktion til et håndværk (2. udgave / ed.). Kbh.: Hans Reitzel.

Kvale, S., \& Nielsen, K. (2013). Mesterlære : læring som social praksis. Kbh.: Nota.

Københavns_Universitet. (2013). Retrieved 30.05., 2014, from http://sund.ku.dk/uddannelse/vejledninginformation/studieordninger/medicin/tidligerekandidatstudieordninger/medicin-ka-2009-13.09.01.pdf

Københavns_Universitet. (2014). Studieordning medicin, KU, 2014. Retrieved 30.05., 2014, from http://sund.ku.dk/uddannelse/vejledninginformation/studieordninger/medicin/tidligerekandidatstudieordninger/medicin-ka-2009-14.02.01.pdf 
Larsen, J.-H., Risør,O., Nystrup, J. \& Charlotte Hedberg. ( 2010). Supervision af videooptagede samtaler. Månedsskr Prakt Lægegern(88. årgang).

Larsen, K., Bundgaard,B. \& A. Steenberger. (2013). Choktal: Psykiatrien mangler mindst 150 speciallæger. Ugeskrift for læger(39/2013), 22222223.

Lave, J. o. W., Etienne. (2003). Situeret læring - og andre tekster. Kbh.: Hans Reitzel.

Muench, J., Sanchez, D., \& Garvin, R. (2013). A review of video review: new processes for the 21st century. Int J Psychiatry Med, 45(4), 413-422.

Nielsen, K., \& Kvale, S. (2003). Praktikkens læringslandskab : at lære gennem arbejde. Kbh.: Akademisk.

Nielsen, K. Ø. ( 2013 ). Sådan er danskerne på Facebook. http://www.dr.dk/Nyheder/Indland/2013/09/19/154530.htm

Parnas, J., Sass, L. A., \& Zahavi, D. (2013). Rediscovering psychopathology: The epistemology and phenomenology of the psychiatric object. Schizophrenia Bulletin, .39(2), pp.

Rajagopal, S., Rehill, K. S., \& Godfrey, E. (2004). Psychiatry as a career choice compared with other specialties: a survey of medical students. The Psychiatrist, 28, 444-446.

Schen, C. R. (2012). Videotaping and writing about patients: lessons from the "Gloria films". Harv Rev Psychiatry, 20(5), 277-280. doi: $10.3109 / 10673229.2012 .726543$

Stalmeijer, R. E., Dolmans, D. H. J. M., Wolfhagen, I. H. A. P., \& Scherpbier, A. J. J. A. (2009). Cognitive apprenticeship in clinical practice: can it stimulate learning in the opinion of students? Advances in Health Sciences Education, 14(4), 535-546. doi: DOI 10.1007/s10459-0089136-0

Syddansk_Universitet. $(2013,12.12 .2013)$. Studieordning Kandidatuddannelsen i Medicin. from http://static.sdu.dk/mediafiles///Files/Information_til/Studerende_ve d_SDU/Din_uddannelse/Medicin/Aktuel_studieordning/Kandidatstudie ordning\%202011\%20-\%20opdateret\%20oktober\%202013.pdf

Varma, A., Bonde, J.P. (2012). Yngre Lægers Arbejdsvilkår 2012.

Ørngreen, R., Buhl,M., Levinsen,K., Birch Andreasen, L. \&, \& Ratleff, P. (2011). Videoproduktioner som læringsressource i universitetsundervisning. Cursiv(8).

Aarhus_Universitet. (2011). Studieordning for Kandidatuddannelse i medicin (2011). from http://studieordning.au.dk/studieordningHTML/753_11-122013_Kandidatuddannelse $\% 20 \mathrm{i} \% 20$ medicin.html 